Revista Calundu - vol. 2, n.1, jan-jun 2018

\title{
PARA NÃO DIZER QUE NÃO FALEI
}

\author{
Marcelo Rodrigues Barreto Regis ${ }^{1}$ \\ DOI: https://doi.org/10.26512/revistacalundu.v2i1.9560
}

"Aira ó, ore gédé pá"

Pensei em começar falando sobre a discriminação, sobre as "intolerâncias", que nossos cultos, nossas tradições e comunidades afro ameríndias são submetidas. Enumeraria as barbaridades cometidas pelos chamados pentecostais ou neopentecostais, no seu discurso raivoso e invadindo nossos espaços sagrados; falaria da revolta que isso causa e o sentimento de impotência que a gente sente diante disso tudo. Citaria a incapacidade, intencional muita das vezes, das esferas de governo ao tratar esta questão. Lembraria também a intencionalidade explícita em ignorar o problema por parte daqueles que encabeçam o governo hoje.

Seria mais um texto denunciando as atrocidades já conhecidas e pedindo "providências às autoridades"; "chover no molhado". Óbvio que denunciar e lutar contra estas ações discriminatórias e "intolerantes", nos mais diversos níveis em que se manifestam, não se discute.

Só que alguma coisa me incomoda nesta luta. Justamente é o como lutar contra tudo isso. Adianto que não tenho receitas prontas ou caminhos revelados. Aqui tentarei levantar algumas questões que poderíamos pensar ao construir, ou reconstruir, nossas narrativas e ações de luta, de resistência. Estas questões se baseiam no que eu entendo ser a formação escravocrata e racista da nossa sociedade e, até certo ponto, na influência simbólica a que mesmo nós, povo de santo, estamos submetidos e, muita das vezes, contaminados.

Esta é minha contribuição com a conversa.

O Brasil foi construído economicamente na escravização de povos, sejam ameríndios, sejam africanos. A força de trabalho escrava foi que garantiu a construção material do país e sustentou oficialmente, durante mais de três séculos, a economia dos centros exploradores europeus. Não só com a exploração e apropriação da produção

\footnotetext{
${ }^{1}$ Airá Tilaió. Axogum (ogan responsável pelos cortes rituais de seu terreiro).
} 
Revista Calundu - vol. 2, n.1, jan-jun 2018

colonial, baseada na mão de obra escrava, mas com o próprio tráfico de escravizados. Ou alguém acha que os "europeus" fizeram tudo isso só por uma perversidade atávica? Sem chance.

O tráfico de escravos foi um dos pilares da economia europeia iniciado no século XVI e perdurou até a revolução industrial. Quando eu era criança a gente ouvia na escola sobre os ciclos econômicos do Brasil. O ciclo da cana, do ouro, do café, movidos pela força de trabalho escravizada sem mencionar em momento algum o tráfico como fonte de sustentação dessa economia colonial. O capitalismo europeu se consolida com a extração das riquezas das colônias e com o tráfico de gente.

O trabalho baseado na escravidão coisifica a força de trabalho. Aquele escravo não é um ser humano, é uma ferramenta de e para o trabalho. A relação não é entre pessoas, o escravo não é “gente", não é outro ser humano. É apenas uma ferramenta comercializada e utilizada até, literalmente, sua última gota de sangue. Sendo assim suas crenças, seus símbolos, sua história não existem ou não tem necessidade de existir.

Se essas relações de trabalho são mantidas a ferro e fogo por mais de 300 anos, é certo que foram naturalizadas nos "corações e mentes" desta sociedade. De um lado, as pessoas que trabalham e produzem e, do outro, o dono do que é produzido e que considera os outros como ferramentas.

Se não é "gente" qualquer manifestação de identidade deste "povo" não existe ou não deve existir. Esta é a base do que está no "não presta", "não serve", "é coisa de negro" (ou índio) e de todos os atos racistas que presenciamos. Ou melhor, que sempre presenciamos. Os exemplos são abundantes e constantes sendo desnecessário listá-los.

Friso que nossa sociedade é racista, construída material e simbolicamente com e na escravidão. Suas classes dominantes (material e simbolicamente dominantes) tentam "destruir" qualquer forma de manifestação que fortaleça a identidade da sua população majoritária de ascendência escravizada, negra e mestiça. Essas ações e práticas discriminatórias não são fenômenos novos ou inusitados. Basta lembrar os registros de invasão de casas de santo no início do século passado ou mesmo as perseguições e prisões de sambistas. Seja quais foram os pretextos para aquelas ações usados naqueles tempos, eles eram só mais uma forma de manifestação racista.

Aqui entram os pentecostais e/ou neopentecostais. Os tempos mudaram. Mas essencialmente, o discurso e os objetivos das suas ações não diferem muito do que já foi feito pela igreja católica. Usei antes o termo “destruir", mas me parece exagerado. É mais como tentassem dizer: "Vocês são escravos. Não são gente. Ponham-se no seu lugar." 
Revista Calundu - vol. 2, n.1, jan-jun 2018

No final das contas é disputar constantemente espaços de poder para que o outro continue como escravo, material e simbolicamente. Esse é o objetivo deles.

Daí é que não acho produtivo, a luta contra o racismo - e contra o racismo religioso mais precisamente - estar baseada em lemas que não consideram o próprio racismo. Lemas como "contra a intolerância", "pela paz" e outros tais tendem a cair na vala comum e não definem nada.

O que significa ser "contra a intolerância"? Se estamos falando de crenças, cultos, formas de perceber o mundo, formas de viver, a abrangência dessa "tolerância" estará circunscrita a estes formatos. Tolero o que acho que deve ser tolerado. Não mais que isso. A garantia do convívio entre essas diversas "tolerâncias" é mediada pelo estado. Este é o espaço de disputa. Pedir ao outro que me "tolere” não é pedido. É súplica. Assim, mesmo com todas as dificuldades que conhecemos, as agressões, invasões etc. tem que ser tratadas como são. Crimes que devem ser apurados, investigados e julgados.

Não pensem que estou, vamos dizer, desestimulando manifestações "contra a intolerância”. Pelo contrário, é necessário denunciar e combater qualquer ato deste tipo. Só que este combate não pode perder a referência de ser um combate ao racismo religioso cujas manifestações são justamente tais atos.

Não tenho ilusões quanto a alguma possibilidade de convencimento destes setores, tropa de choque do racismo, para serem mais "tolerantes" ou atender a apelos de um pretenso convívio pacífico baseado em interpretações de crenças. Não me atrevo a dizer o que as crenças deles defendem ou não estão certas ou não. Isso sinceramente não me interessa e faz parte da visão de mundo lá deles. Somos diferentes nas crenças, nas formas de ver o mundo, no viver e pronto. O convívio dessas visões de mundo conflituosas só é garantido pelo estado. Cabe a nós definirmos melhor como atuar nesses espaços estatais já tão restritos.

E como lutar fora destes espaços, no dia a dia? E aqui temos um problema bem maior. A contaminação dos valores simbólicos da sociedade racista pelas nossas próprias comunidades religiosas.

Todos falam, quando nos referimos aos pentecostais e neopentecostais, que eles têm poder, dinheiro, canais de televisão, deputados etc. etc. etc. Mas por que tiveram esse crescimento de influência tão acentuado nos últimos quarenta, cinquenta anos, mais ou menos? Como tiveram uma inserção tão grande nas comunidades pobres e periféricas? Se respondermos porque eles tem poder, dinheiro, canais de TV etc. pode ser uma resposta mais não explica muita coisa, parece cobra engolindo a cauda. 
E por que será que o discurso contra nossa religião é baseado justamente na identificação de elementos das nossas crenças como elementos malignos lá da religião deles? Eles não têm um discurso genérico, muito utilizado há séculos pela igreja católica, contra heresia ou contra discípulos do mal. Eles constroem seu discurso justamente com os elementos, muito bem identificados, que estavam presentes nas comunidades pobres e periféricas, que faziam e fazem parte das suas crenças.

Digo isso porque creio que nestes anos de ascensão dos crentes os terreiros “esqueceram” seus vínculos com a própria comunidade a que dava sustentação religiosa. Em algum momento, os terreiros começaram a tentar ser reconhecidos pela classe média urbana e branca que, estando fora das comunidades, não tinham obviamente os mesmos interesses, problemas, necessidades destas. Até aí, tudo bem. Pode ser até que fosse necessário este direcionamento para o reconhecimento das nossas casas como parte constituinte da sociedade. O problema é quando essa busca por reconhecimento passa a ser sinônimo de ganhar importância, seja para tentar ter influência em esferas fora da sua comunidade, seja pela arregimentação de adeptos também de fora.

Os vínculos (aqueles interesses, necessidades e problemas comuns) vão se esgarçando já que o foco é a aproximação com os de fora, e a importância da comunidade para a casa, e da casa para a comunidade, vai diminuindo. Os crentes disputam este espaço que alguns deixaram.

Motumbá.

Recebido em: 03/05/2018

Aceito em: 30/05/2018 